\title{
PEMAHAMAN PELATIH FUTSAL TERHADAP PENANGANAN CEDERA ENGKEL
}

\author{
Rahmat Sanusi \\ Program Studi Penjaskesrek, Universitas Karimun \\ Jln. Raya Komp. Timah, Tlk. Uma, Tebing, Kabupaten Karimun, Kepulauan Riau \\ e-mail: rahmatsanusi25@gmail.com
}

\begin{abstract}
Abstrak
Cedera engkel merupakan cedera paling sering yang terjadi dalam olahraga. Dislokasi pada tulang atau ligamen adalah penyebab utama dalam kasus cedera engkel ini hingga menyebabkan cedera kronis. Pengetahuan pelatih dalam memberikan pertolongan pertama, khususnya pengetahuan mereposisi cedera engkel sangat diperlukan. Penelitian ini bertujuan untuk mengetahui tingkat pemahaman pelatih futsal terhadap penanganan cedera engkel. Metode penelitian ini adalah metode deskriptif. Instrumen penelitian berupa angket, wawancara dan tes unjuk kerja dengan subjek penelitian sebanyak 27 orang. Data yang diperoleh dianalisa dengan menggunakan statistik deskriptif. Hasil analisa data menunjukkan bahwa nilai rata-rata sebesar 2,37 untuk pengetahuan teori dan nilai rata-rata sebesar 2,24 untuk pengetahuan praktek. Dapat disimpulkan masih rendahnya pemahaman pelatih dalam penanganan cedera engkel.
\end{abstract}

Kata Kunci: Pemahaman, cedera, engkel dan pelatih

\begin{abstract}
Ankle injuries are the most common injuries that occur in sports. Dislocations of bones or ligaments are the main cause in these ankle injury cases causing chronic injury. The trainer's knowledge in providing first aid, especially knowledge of repositioning ankle injuries is very much needed. This study aims to determine the level of understanding of futsal coaches in handling ankle injuries. This research method is descriptive method. Research instruments in the form of questionnaires, interviews and performance tests with 27 research subjects. The data obtained were analyzed using descriptive statistics. The results of data analysis show that the average value is 2.37 for theoretical knowledge and the average value is 2.24 for practical knowledge. It can be concluded that the trainer's understanding of handling ankle injuries is still low
\end{abstract}

Keywords: Understanding, injuries, ankle and coach

\section{PENDAHULUAN}

Cedera angkel merupakan cedera yang paling umum terjadi pada semua aktivitas olahraga, baik latihan maupun bertanding. Calatayud et al (2014) menegaskan keseleo (sprain) adalah cedera yang paling sering terjadi pada engkel baik olahraga tim atau individu, di lapangan atau di ruangan yang mengakibatkan perubahan struktur dan fungsional sehingga menyebabkan kerusakan yang lebih parah. Selama aktivitas fisik terutama olahraga yang berhubungan dengan kontak 
fisik atau tidak, menuntut aktivitas yang tinggi dari engkel. Aktivitas yang dimaksud berubah tekanan dari beban tubuh dan mobilitas yang tinggi dari sendi engkel. Childs (2012) menyebutkan sprain engkel menjadi cedera yang paling sering terjadi dalam aktivitas atletik dan dapat terjadi tiba-tiba karena inversion. Renstrom et al. (2014) mengatakan bahwa cedera engkel merupakan cedera yang paling sering terjadi hampir semua cabang olahraga terutama basket, voli dan sepak bola.

Perkembangan minat olahraga sepak bola dewasa ini meningkat secara spesifik berawal dari sepakbola menjadi futsal dengan sedikit modifikasi dari aturan dan ukuran lapangan. Futsal menjadi salah satu olahraga paling diminati baik secara profesional maupun amatir. Perkembangan olahraga futsal berdampak dengan tingginya kasus cedera selama permainan berlangsung yaitu cedera engkel. Tempo bermain dan pergerakan yang cepat memicu potensi cedera engkel cukup tinggi disebabkan benturan body contact maupun mobilitas yang tinggi. Menurut Fousekis, Tsepis, \& Vagenas (2012) mayoritas cedera yang terjadi dalam sepak bola/ futsal (68\%-88\%) terjadi pada lower ekstremitas yang sebagian besar pada engkel dan paha. Cedera engkel menyumbang hampir 14\%-17\% dalam aktivitas sepakbola/ futsal.

Tingginya angka cedera selama permainan futsal khususnya selama aktivitas latihan dan pertandingan tidak sejalan dengan penanganan cedera yang dihasilkan. Berdasarkan pengamatan di lapangan diamati masih rendahnya peran pelaku olahraga terutama pelatih dan atlet dalam memberikan bantuan kepada atlet yang mengalami cedera. Ketika atlet mengalami cedera pelatih hanya meminta atlet untuk keluar dari lapangan, menekuk kaki dorsifleksion dan plantar fleksion, memberikan balsem, kompres es dan beristirahat. Tindakan ini sepenuhnya tidak salah namun tidak tepat dalam upaya penanganan mengingat cedera engkel yang tidak ditangani dengan cepat dan tepat akan menyebabkan tingkat cedera yang lebih parah dari akut menjadi kronis.

Sebagai pelaku olahraga yang terlibat banyak dalam aktivitas olahraga, seorang pelatih hendaknya memiliki pengetahuan dan keterampilan dasar terkait penanganan cedera, khususnya cedera engkel yang sering terjadi dalam olahraga 
futsal. Dengan keterampilan penanganan cedera khususnya cedera engkel menujukkan profesionalisme pelatih dalam menyusun rencana latihan sebagai upaya pencapaian prestasi. Penelitian ini dimaksudkan untuk mengetahui pemahaman pelatih dalam penanganan cedera engkel pada baik secara teori maupun praktek. Hasil penelitian diharapkan menjadi tolok ukur untuk meningkatkan kapasitas dan profesionalisme pelatiha futsal dalam menekuni bidangnya.

\section{Cedera Engkel}

Penting untuk memahami pengertian cedera sebagai kerusakan yang terjadi pada bagian tubuh tententu akibat faktor-faktor tertentu. Berdasarkan rentang waktu dan kronologinya cedera memiliki dua istilah yang sering kali keliru untuk dipahami, yaitu akut dan kronis. Cedera akut adalah cedera yang terjadi secara spontan tanpa riwayat cedera pada lokasi yang sama sebelumnya, proses penyembuhanya relatif singkat dan tidak menimbulkan efek berkepanjangan. Kronis diartikan sebagai cedera yang terjadi berulang-ulang dengan lokasi dan jenis cedera yang sama sehingga efek yang ditimbulkan berkepanjangan dan membutuhkan waktu yang lama untuk penyembuhan. Menurut Kadel (2018) cedera akut merupakan kejadian tunggal yang dikarenakan tekanan berlebihan dan trauma dengan persentase 40\%-50\% dari keseluruhan cedera pada olahraga. Kronis diartikan sebagai cedera yang telah berlangsung lama dan akan kembali terjadi pada saat-saat tertentu dengan proses penyembuhan relatif lama. Hubbard \& Hicks-Little (2011) menjelaskan bahwa rasa nyeri/ keseleo pada angkel yang terjadi berulang-ulang disebut chornic angkle instability atau ketidakstabilan kronis angkel. Misalnya, cedera engkel yang ditangani dengan baik dan sembuh dalam waktu 1-2 minggu dan keluhan rasa nyeri dan sakit tidak muncul lagi dapat diklasifikasikan sebagai cedera akut.Paparan sebelumnya menjelaskan bahwa cedera engkel merupakan cedera yang paling umum terjadi selama aktivitas olahraga. Engkel merupakan titik persambungan pada tulang tibia dan ulna dengan tulang talus dan calcaneus. Talus dan calaceneus merupakan bagian dari metatarsal (kaki/ telapak kaki) yang tersusun 
dari empat bagian yaitu ligamen, tendon, tulang dan sedikit otot. Cedera engkel secara spesifik mengarah kerusakan pada ligamen seperti putus atau robek dan dislokasi pada tulang. Ditinjau dari gerakan, cedera angkel dapat terjadi karena dua faktor yaitu inversion dan version. Inversion adalah arah patahan menekuk ke bagian dalam. Version adalah patahan engkel yang menekuk ke arah bagain luar. Jika tidak mendapatkan penanganan yang tepat, cedera engkel dapat meningkat dari akut menjadi kronis sehingga mengganggu peforma atlet dalam berlatih dan bertanding.

\section{Anatomi Engkel}

Prinsip dasar susunan anatomi tubuh manusia adalah bagian penting dalam olahraga. Struktur tubuh manusia memiliki kesamaan cara kerja seperti puzzle, yaiut dari kepingan-kepingan tulang lainnya dengan bentuk dan ukuran yang berbeda kemudian saling berhubungan satu dengan lainnnya yang direkatkan oleh jaringan lunak ligamen. Pada tubuh manusia terdapat dua jaringan lunak pengikat rangka, yaitu ligamen dan tendon. Ligamen adalah penghubung antar tulang dengan tulang sedangkan ligamen adalah penghubung antar otot dengan tulang. Tendon sendiri masih satu bagian dari otot atau bagian paling ujung dari otot yang berwarna putih lebih lebih kenyal dari pada otot.

Engkel merupakan salah satu bagian tubuh yang banyak terdapat jaringan lunak dan sedikit otot. Walker (2013) toluctural atau sendi engkel merupakan engsel dan yang terdiri dari tibia, fibula, talus dan calcaneus yang mendukung gerakan fleksi dan ektensi pada kaki. Engkel merupakan persambungan/ pertemuan antara dua kelompok besar tulang pada tungkai. Kelompok pertama terdiri dari tulang tibia dan fibula, kelompok kedua terdiri dari dari tulang besar utama telapak kaki (metatarsal) yaitu talus dan calcaneus. Kaki (metatarsal) memiliki tujuh tulang utama (tidak termasuk tulang-tulang jari jari kaki) dari tumit kaki hingga titik tengah dari permukaan metatarsal yang terdiri dari talus dan calcaneus. Pertemuan dua kelompok tulang ini membentuk sendi dengan yang diikat dengan ligament, cuboid, navicular, lateral cuneiform, intermediate cunierform dan media cunieform. 
Metatarsal merupakan salah satu struktur tulanng yang paling kuat setelah lutut, karena ditinjau dari perannya yang mampu menopang berat badan dan terlebih lagi pada saat aktivitas olahraga, mobilitas persendian metatarsal dituntut sangat tinggi. Sedikitnya terdapat 8 tulang penyusun metatarsal yang terdiri dari 1) calcaneus, 2) cuboid, 3) lateral cunieform, 4) intermediate cuneiform, 5) navicular, 6) talus, 7) tibia dan 8) fibula.

Metatarsal tersusun oleh tulang dengan karakteristik bentuk yakni bulat, pendek dan tidak beraturan. Bentuk tulang seperti itu, memperkecil potensi terjadinya patah tulang pada telapak kaki, ini menjadi alasan benturan yang keras saat beraktivitas olahraga berpotensi kecil dapat mematahkan atau tulang-tulang yang terdapat pada tarsal.

Keseluruhan jenis tulang tersebut diikat oleh jaringan lunak yaitu ligamen. Pada tarsal sedikitnya terdapat 25 buah ligamen yang tersusun mengikat tulangtulang pada engkel. Ligamen memiliki peran vital dalam mendukung aktivitas gerak pada engkel yang berhubungan pada tiitk pertemuan dua tulang berbeda. Ligament menjaga masing-masing tulang untuk tetap berdekatan dan berada pada posisinya. Mulligan (2011) menyatakan secara kolektif ligament menjaga diastasis sendi. Diastasis adalah pemisahan atau terpisahnya bagian-bagian yang tersambung.

Kekuatan engkel bergantung pada kekuatan ligamen. Kekuatan ligamen sendiri bergantung pada instensitas cedera dan kekuatan engkel. (Czajka, Tran, Cai, \& DiPreta, 2014). Situasi ini menunjukan bahwa penurunan kualitas engkel mengindikasikan riwayat cedera yang berkelanjutan. Glloway \& Hannaford (2010) mengatakan terdapat tiga ligamen inti yang mendukung pergerakan engkel. Selama berjalan dan berlari ligament menyeimbangkan persendian metatarsal atas beban berat badan dan pergerakan. Jika persendian bergerak/ berguling berlebihan sehingga menghasilkan tekanan yang besar menyebabkan ligamen robek atau putus. Robekan atau putus pada ligamen menyebabkan susunan tulang menjadi tidak stabil sehingga memicu terjadinya dilokasi. 


\section{Sprain atau Terkilir}

Salah satu cedera engkel yang sering dialami atlet adalah sprain atau yang lebih dikenal dengan keseleo. Sprain merupakan cedera pada ligamen yang mengakibatkan robek hingga putus. Childs (2012) mengatakan sprain (cedera inversion) melibatkan tertariknya dan putus ligamen akibat aktivitas gerak yang berlebihan. Hubbard \& Hicks-Little (2011) menyatakan ligamentum talofibular anterior merupakan sebagai ligamen yang paling lemah dan rentan serta menjadi ligamen pertama yang akan terluka (robek/ putus) saat terjadinya sprain. Menurut Van Den Bekerom, Kerkhoffs, Mccollum, Calder, \& Van Dijk, 2013 sendi tibiotalar dianggap sebagai sendi engkel yang sederhana tetapi jauh lebih kompleks pada ligamen pergelangan kaki lateral terdiri dari tiga ligamen yaitu talofibular anterior, ligamen calcaneofibular dan ligamentum talofibular postterior.

Sprain atau terkilir menjelaskan situas tertarik ligamen dan berpotensi terjadinya robekan. Sprain pada dikaitkan dengan kondisi tarsal yang mengalami tekanan akibat kejadian berputar yang disebut dengan inversion dan version. Kajadian inversion melibatkan tiga ligament yaitu pada posterior talobifular ligament, anterior talobifular ligament dan calcaneo talobifular. Diantara 80\% cedera ligament engkel disebabkan eksplosif inversion/ supinasi. Cedera gerakan sering kali terjadi di persendian subtalar dan merobek anterior talobifular ligament yang memiliki batas beban paling rendah diantara ligament lateral pada engkel. (Fong, Chan, Mok, Yung, \& Chan, 2009).

Fong et al (2009) menegaskan bahwa diantara semua ligamen talofibular anterior merupakan yang terlemah karena kemampuan menahan beban yang rendah dengan kekuatan 138,9 N. Nilai ini merupakan setengah dari talibibula posterior yaitu 261,2 $\mathrm{N}$ dan sepertiga dari calcaneofibular ligament yaitu 345,7 N. igament talofibular anterior memiliki panjang $20-25 \mathrm{~cm}$, lebar 7-10 $\mathrm{mm}$ dan ketebalan $2 \mathrm{~mm}$. Nilai ini diperoleh berdasarkan uji mekanik pada ligamen yang berada pada pergelangan kaki. Berdasarkan hal di atas dapat disebutkan talofibular anterior merupakan ligamen paling rentan mengalami sprain. 


\section{Strain}

Pada dasarnya Strain tidak jauh berbeda dengan cedera sprain. Jika sprain terjadi pada ligament maka strain terjadi pada tendon. Strain terjadi akibat jangkauan yang berlebih, akses mobiltitas yang tidak terkontrol, landasan pendaratan yang tidak stabil dan penurunan kemampuan pada tendon itu sendiri. Sports Injuries (2011) menjelaskan strain sebagai akibat dari gerakan memutar dan menarik otot tendon yang merupakan jaringan ikat penghubung otot dengan tulang. Strain dapat menjadi cedera akut yang tidak disadari karena penegangan yang berlebihan atau terlalu banyak kontraksi. Gejala yang terjadi adalah rasa nyeri, kejang otot dan kehilangan kekuatan.

\section{Dislokasi}

Dislokasi diartikan sebagai perpindahan posisi. Rolf (2007) cedera dislokasi dapat menjadi cedera permanen. jika ditinjau dari beberapa hal tendon atau ligament yang putus atau cedera parah sehingga tidak memungkinnkan kembali pada $100 \%$ kemampuan. Kondisi dapat diartikan cedera kronis dimana proses penyembuhan memerlukan waktu yang lama atau bahkan tidak dapat sembuh kembali seperti biasa. Minigh (2007) ketidakstabilan sendi merupakan gangguan yang meliputi dislokasi, subluksasi dan kelonggaran.subluksasi merupakan dislokasi parsial sendi. Misalnya keluarnya bola dari semua atau sebagian dari soket. Kejadian ini disebabkan lemahnya struktur jaringan ikat yaitu ligament (rusak,putus atau robek) yang mendukung sendi. Menetrey (2014) dislokasi merupkan cedera yang banyak terjadi dalam olahraga yang melibatkan persendian pada engkel dan lutut. Hal ini terjadi karena menurunnya fungsi dari ligamen sebagai jaringan ikat.

Tidak banyak pelaku olahraga yang begitu memahami proses dan penanganan dislokasi. Dalam olahraga dislokasi dimaknai sebagai berpindahnya posisi tulang dan ligamen dari posisi sebenarnya yang diakibatkan oleh benturan keras, penurunan kualitas tulang, ligament dan sendi hingga cedera kronis. melihat prinsip kerja dari puzle, dapat dipahamu bahwa agar rangka dapat bekerja secara optimal, tulang harus tersusun erat dan berada pada posisi sebenarnya. Menurut 
Dislokasi adalah hal yang luar biasa menyakitkan sering terjadi akibat pukulan pada persendian di antara tulang. Berbeda dengan tulang patah. Dislokasi terjadi dengan posisi tulang tetap utuh, tetapi posisi tulang (baik sebagian tau seluruhnya) berpindah dari posisi normalnya. Ini menyebabkan kelainan bentuk atau tidak terlihat sama sekali namaun memerikan efek nyeri berkepanjangan, seperti bagian tulang terlihat menonjol. Dislokasi dapat terjadi pada sendi yang lebih besar, seperti bahu, siku, atau lutut, serta pada sendi yang lebih kecil, seperti jari tangan dan kaki. Sports Injuries (2011) menjelaskan bahwa jika dua tulang yang berdekatan membentuk sendi secara tiba-tiba terpisah, dapat diindikasikan bahwa itu merupakan kejadian dislokasi. Dislokasi merupakan cedera yang paling menakutkan bagi para atlet. Dislokasi adalah situasi berpindah atau bergesernya posisi salah satu tulang dari kedudukan aslinya.

\section{Penanganan Cedera}

Pemahaman pelaku olahraga tentang penangan cedera sangat diperlukan mengingat aktivitas olahrag sangat rentan dengan cedera. Memiliki kemampuan menangani cedera menjadi keterampilan yang dapat menunjang karir dan memberikan manfaat secara luas. Termasuk dalam upaya penangan cedera engkel yang merupakan cedera paling umum dalam aktivitas olahraga. Penangan dan perwatan adalah dua hal yang berbeda, terutama ditinjau dari kejadian dan tindakan. Penangan atau dalam istilah lain disebut dengan handling yang cendrung pada tindakan nyata sebagi bentuk pertologan pertama kepada korban saat terjadinya cedera. Proses penanganan cedera terbukti sangat membantu pelatih dan atlet selama akivitas olahraga untuk mencegah cedera yang lebih parah, mengembalikan peforma atlet untuk kembali bertanding termasuk penanganan cedera engkel.

\section{Active Range Of Motion (AROM) Test}

Sebelum melakukan tindakan penanganan, diawali dengan cek dan ricek sebagai bentuk diagnosa. Lakukan AROM dengan cara minta korban lakukan plantar flexion, dorsiflescin, inversion dan version sembari salah satu tangan 
memenga pangkal tulang tubia dan fibula, dan tangan yang lain memegang dengan lembut plantar dan tidak menekan. Perhatikan disekeliling angkel, jika terdapat titik biru atau memerah di bahaw kulit diikuti dengan pembekakan secara cepat, maka besar kemungkinan terjdinya robek atau putus pada ligamen (Renstrom et al., 2014).

\section{Reposisi}

Reposisi menjadi teknik penanganan cedera yang memiliki peran sangat penting. Repoisi merupakan antonim dari dislokasi yang berati mengembalikan poisisi tulang/ sendi agar kembali pada posisi aslinya. Prinsip dasar dari reposisi adalah strech. Peran dari ROM yang dibahas sebelumnya adalah untuk menghidari robekan yang leih besar ketika dilakukan repoisi. Pada engkel titik kunci reposisi adalah pada tulang calcaneus atau tumit kaki. Setelah melakukan AROM dan dipastikan tidak ada robekan besar atau putus, langkah maka langkah berikutnya adalah dengan melakukan reposisi. Sculco et al (2016) menjelaskan bahwa patahan pada engkel terutama pada tulang yang berada pada bagian metatarsal membutuhkan penanganan yang intensif yaitu operasi. Cedera jenis ini dapat mengakibatkan dislokasi atau pergeseran dan berpindahnya tulang.

\section{METODE}

\section{Rancangan Penelitian}

Rancangan penelitian ini adalah menggunakan pendekatan deskriptif tentang tingkat pemahaman pelatih futsal terhadap penanganan cedera engkel. Pendekatan deskriptif adalah penelitian yang bertujuan menggambar tentang situasi, kondisi atau fenomena tertentu untuk mendapatkan informasi atau kebenaran. Berdasarkan hal tersebut penelitian ini bertujuan untuk mendapatkan informasi tentang pemahaman pelatih futsal terkait penanganan cedera.

\section{Subjek Penelitian}

Sampel dalam penelitian ini menggunakan teknik total sampling yang artinya keseluruhan populasi dijadikan sampel. Subjek dalam penelitian ini 
melibatkan 27 orang pelatih futsal yang berada dilingkungan Kab.Karimun Provinsi Kepulauan Riau.

\section{Teknik dan Alat Pengumpulan Data}

Teknik pengumpulan data dilakukan dengan wawancara, penyebaran kuisioner sebanyak 30 pernyataan yang diuji reabilitasnya menggunakan teknik alpha Cronbach dengan perolehan nilai sebesar 0,739 dan dinyatakan reliabel. Berikutnya adalah melakukan tes unjuk kerja pelatih dalam melakukan penanganan cedera olahraga.

\section{Teknik Analisa Data}

Teknik analisa data yang digunakan dalam penelitian ini adalah statistik deskriptif persentase. Data yang diperoleh akan dimasukan kedalam klasifikasi kategori menurut Sudijono (2009) untuk menentukan hasil akhir tingkat pemahaman wasit yang dijelaskan sebagai berikut:

Tabel 1 Klasifikasi Ketegori Persentase

\begin{tabular}{lc}
\hline \multicolumn{1}{c}{ Nilai } & Kategori \\
\hline $80 \%-100 \%$ & Sangat Tinggi \\
\hline $66 \%-79 \%$ & Tinggi \\
\hline $56 \%-65 \%$ & Sedang \\
\hline $46 \%-55 \%$ & Rendah \\
\hline$<45 \%$ & Sangat Rendah \\
\hline
\end{tabular}

\section{HASIL DAN PEMBAHASAN}

\section{Hasil}

Penelitian ini dilakukan di Kabupaten Karimun Provinsi Kepulauan Riau dengan melibatkan 27 orang pelatih futsal. Pengumpulan data dilakukan dengan penyebaran angket dan pengamatan unjuk kerja/ praktek tentang penanganan cedera terutama keterampilan reposisi cedera engkel. Hasil data yang diperoleh kemudian dianalisa dengan memasukan kedalam nilai kategori kuantitatif. Untuk mengukur tingkat pemahaman, maka dilakukan dua jenis tes yaitu tes pengetahuan secara teori dan tes unjuk kerja atau keterampilan secara langsung. Berikut diproleh data untuk pemahaman dosen berdasarkan pengetahuan secara teori yaitu sebagai berikut: 
Tabel 2 Hasil Skor Pemahaman Pelatih Futsal Terhadap Penanganan

Cedera Engkel

\begin{tabular}{|c|c|c|c|c|}
\hline \multirow{2}{*}{ Sampel } & \multicolumn{2}{|r|}{ Teori } & \multicolumn{2}{|c|}{ Keterampilan } \\
\hline & Skor & Kategori & Skor & Kategori \\
\hline N 1 & 1,93 & Sedang & 2,1 & Sedang \\
\hline $\mathrm{N} 2$ & 1,69 & Sedang & 1,64 & Sedang \\
\hline N 3 & 1,82 & Sedang & 1,73 & Sedang \\
\hline $\mathrm{N} 4$ & 1,97 & Sedang & 0,54 & Rendah Sekali \\
\hline N 5 & 0,66 & Rendah Sekali & 2,1 & Tinggi \\
\hline N 6 & 2,58 & Tinggi & 2,87 & Tinggi \\
\hline N 7 & 1,49 & Rendah & 2,21 & Rendah \\
\hline N 8 & 1,95 & Sedang & 2,05 & Rendah \\
\hline N9 & 3,16 & Tinggi & 3,17 & Tinggi \\
\hline N 10 & 2,33 & Sedang & 2,44 & Tinggi \\
\hline N 11 & 2.14 & Tinggi & 1,62 & Rendah \\
\hline $\mathrm{N} 12$ & 1,54 & Rendah & 0,93 & Kurang \\
\hline $\mathrm{N} 13$ & 0,77 & Rendah & 1,44 & Kurang \\
\hline $\mathrm{N} 14$ & 2,4 & Sedang & 2,2 & Sedang \\
\hline $\mathrm{N} 15$ & 1,94 & Sedang & 2,31 & Sedang \\
\hline N 16 & 0,65 & Rendah Sekali & 0,77 & Rendah Sekali \\
\hline N 17 & 2,78 & Tinggi & 2,92 & Tinggi \\
\hline $\mathrm{N} 18$ & 0,67 & Rendah Sekali & 0,54 & Rendah Sekali \\
\hline N 19 & 2,38 & Sedang & 1,97 & Sedang \\
\hline $\mathrm{N} 20$ & 0,69 & Rendah Sekali & 0,71 & Rendah Sekali \\
\hline $\mathrm{N} 21$ & 2,41 & Sedang & 2,44 & Tinggi \\
\hline $\mathrm{N} 22$ & 2,12 & Sedang & 2,02 & Sedang \\
\hline $\mathrm{N} 23$ & 1,97 & Sedang & 2,04 & Sedang \\
\hline $\mathrm{N} 24$ & 1,88 & Sedang & 1,97 & Sedang \\
\hline $\mathrm{N} 25$ & 1,67 & Sedang & 0,62 & Rendah Sekali \\
\hline $\mathrm{N} 26$ & 2,4 & Sedang & 2,21 & Sedang \\
\hline $\mathrm{N} 27$ & 1,98 & Sedang & 1,32 & Rendah \\
\hline Min & & 0,65 & & \\
\hline Max & & 3,16 & & \\
\hline Mean & & 1,85 & & \\
\hline $\mathrm{SD}$ & & 0,67 & & \\
\hline Kategori & & Sedang & & \\
\hline
\end{tabular}


Berdasarkan hasil skor pada Tabel 2, selanjutnya data dianalisis dengan menggunakan statistik deskriprif untuk mengetahui persentase dari skor yang telah diperoleh. Untuk tingkat pengetahuan teori tentang teknik dasar penanganan cedera engkel dipaparkan pada tabel berikut:

Tabel 3 Pemahaman Penanganan Cedera Engkel

\begin{tabular}{lclcc}
\hline No & Interval & Kategori & f & \% \\
\hline 1 & $80 \%-100 \%$ & Tinggi Sekali & 0 & 0 \\
\hline 2 & $66 \%-79 \%$ & Tinggi & 3 & 11,11 \\
\hline 3 & $56 \%-65 \%$ & Sedang & 17 & 62,96 \\
\hline 4 & $46 \%-55 \%$ & Rendah & 3 & 11,11 \\
\hline 5 & $<45 \%$ & Rendah Sekali & 4 & 14,81 \\
\hline \multicolumn{7}{c}{ Total } & $\mathbf{2 7}$ & $\mathbf{1 0 0}$ \\
\hline
\end{tabular}

Berdasarkan Tabel 3, diketahui sebanyak 4 orang mendapatkan kategori rendah sekali dengan persentase $14,81 \%$. sebanyak 3 orang dengan kategori rendah persentase $11,11 \%$. Sebanyak 17 orang kategori sedang dengan persentase sebesar $62,96 \%$. sebanyak 3 orang untuk kategeori tinggi dengan persentase sebesar $11,11 \%$ dan untuk ketegori tinggi sekali tidak ada sama sekali. Untuk lebih jelas digambarkan pada grafik 1 di bawah ini.

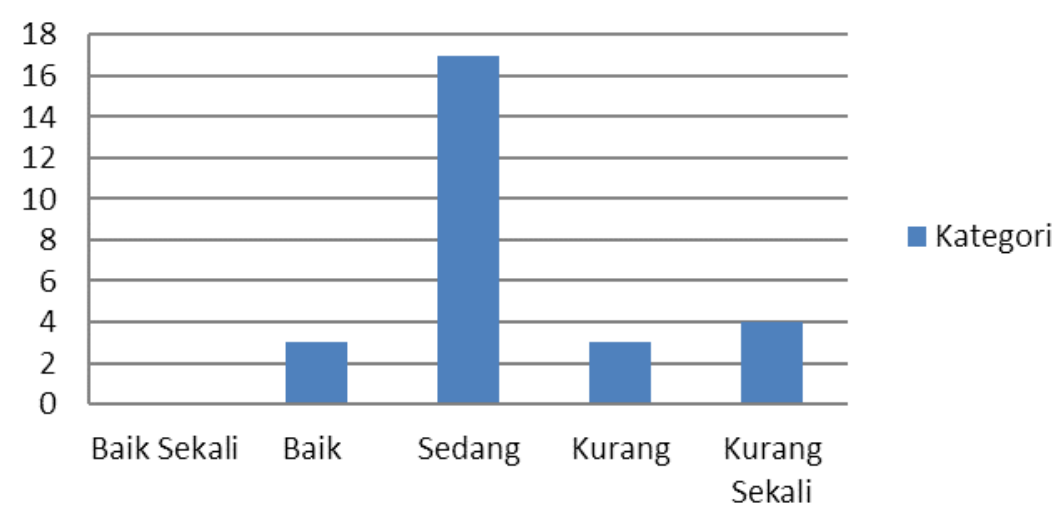

\section{Gambar 1 Grafik Tingkat Pemahaman Teori Tentang Penanganan Cedera Engkel}

Analisa berikutnya adalah pemahaman secara praktek keterampilan penanganan cedera engkel dengan teknik repoisi. Hasil analisa data untuk pemahaman secara praktek dipaparkan pada tabel berikut: 
Tabel 4 Keterampilan Penanganan Cedera Engkel

\begin{tabular}{lcccc}
\hline No & Interval & Kategori & Frekuensi & \% \\
\hline 1 & $80 \%-100 \%$ & Tinggi Sekali & - & - \\
2 & $66 \%-79 \%$ & Tinggi & 6 & 22,22 \\
3 & $56 \%-65 \%$ & Sedang & 13 & 48,14 \\
4 & $46 \%-55 \%$ & Rendah & 3 & 11,11 \\
5 & $<45 \%$ & Rendah Sekali & 5 & 18,51 \\
\hline \multicolumn{7}{r}{ Total } & & 27 & 100 \\
\hline
\end{tabular}

Berdasarkan paparan data di atas dapat dijelaskan pemahaman keterampilan praktek penanganan cedera engkel pada kategori rendah sekali sebanyak 5 orang dengan persentase sebesar $18,51 \%, 4$ orang untuk kategori rendah dengan persentase sebesar $11,11 \%, 13$ orang untuk kategori sedang dengan persentase sebesar 48,14\%, 6 orang untuk kategori tinggi dengan persentase sebesar $14,81 \%$, dan untuk kategori tinggi sekali tidak ada. Untuk lebih jelas dapat dilihat pada grafik di bawah ini:

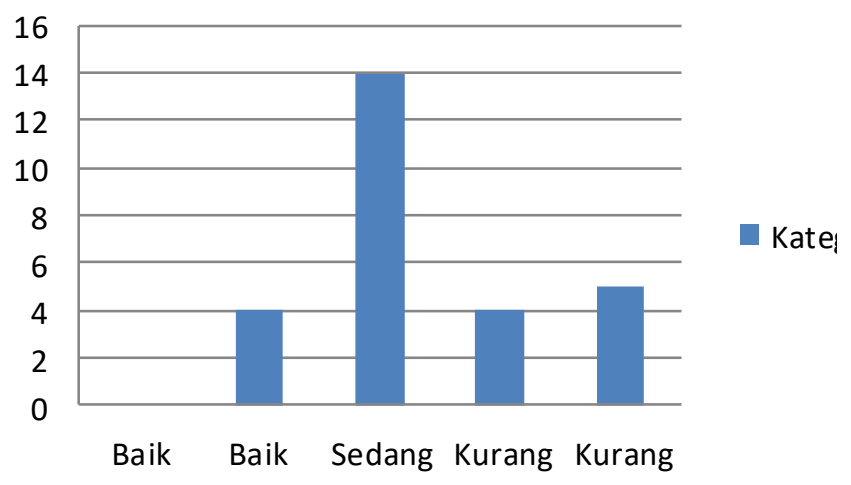

Gambar 2 Grafik Tingkat Pemahaman Keterampilan Penanganan Cedera Engkel

\section{Pembahasan}

Penanganan cedera engkel bertujuan untuk mencegah terjadinya cedera kronis pada engkel yang pada umumnya terjadi dislokasi pada tulang atau ligamen disekitar metatarsal. Pemahaman akan penanganan cedera engkel memfokuskan pada kemampuan reposisi pada saat terjadi cedera dan melaksanakan prinsip pertolongan pertama yaitu rest (mengistirahatkan), ice (kompres es), compres 
(pembalutan) dan elevate (meninggikan) yang disingkat dengan RICE. Pelatih memiliki peran yang krusial sebagai orang terdekat dengan atlet yang dapat memberikan pertologan pertama ketika terjadi cedera. Whatman, Walters \& Schluter (2018) menjelaskan bahwa pelatih memiliki intervensi terhadap keselamatan atlet selama bertanding, sehingga pemahaman perilaku tentang cedera antara atlet dan pelatih sangat diperlukan dalam aktivitas olahraga. Pasanen et al (2017) menambahkan setiap aktivitas olahraga memiliki resiko cedera yang sangat tinggi sehingga keterlibatan fisioterapis, pelatih dan atlet terhadap pemahaman dan keterampilan terhadap cedera adalah hal yang penting. Memperkuat pendapat tersebut Pryor et al (2017) menekankan bahwa peran dan kemampuan pelatih terhadap cedera harus termplementasi dengan baik dalam setiap aktivitas olahraga.

Paparan data di atas menunjukkan secara keseluruhan nilai mean adalah sebesar 1.85 untuk pengetahuan teori dan 1.81 untuk pengetahuan praktek. Angka ini menunjukkan kategori sedang. Hasil analisa data menujukkan masih rendahnya pemahaman pelatih dalam penanganan cedera engkel. ini dibuktikan dari 27 orang pelatih hanya 5 orang atau 20\% yang memiliki pemahaman penanganan cedera angkel yang baik. Kemampuan pelatih berada pada kategori cukup sebanyak 16 orang atau $60 \%$ dari keseluruhan objek penelitian dan sisanya masih pada katageori kurang.

Melihat dari paparan angka tersebut menjadi kekhawatiran tersendiri terhadap profesionalisme seorang pelatih saat beraktivitas di lapangan, mengingat peran pelatih ikut terlibat dalam upaya menjaga kondisi fisik atlet termasuk memberikan perlindungan, penanganan, pertolongan dan perawatan cedera selama berolaharaga. Rendahnya pemahaman pelatih dalam penanganan cedera engkel mengindikasi beberapa faktor sebagai berikut:

\section{Minimnya peningkatan kompetensi dibidang Sport Scince}

Masih jarang diadakannya workshop dan pelatihan di Kabupaten Karimun dengan dengan tema sport science yang membahas tentang kondisi fisik, program latihan, kesehatan dan rehabilitasi cedera olahraga yang dapat meningkatkan kompetensi pelatih dibidang yang ditekuni. Baik yang dilaksanakan oleh 
pemerintah, asosiasi, organisasi dan lain sebagaianya. Terbatasanya pola pikir subjek penelitian yang beranggapan bahwa melatih hanya berkaitan dengan strategi permainan dan latihan sehingga tidak tertarik untuk berpartisipasi dalam workshop dan pelatihan yang diadakan di luar kota.

\section{Latar belakang pendidikan}

Hasil investigasi menujukan hampir $70 \%$ pelatih tidak memiliki latar belakang pendidikan di bidang olahraga. Cendrung dengan latar belakang atlet dan latar belakang profesi yang tidak berkaitan dengan olahraga. Hal ini berhubungan dengan pemahaman dan pengetahuan secara teori dan praktik tentang prinsip-prinsip dasar dalam olahraga khususnya prinsip-prinsip latihan.

Dua faktor di atas merupakan sebagian kecil dari penyebab rendahnya pemahaman pelatih dalam penanganan cedera engkel pada atlet. Penting bagi pelatih untuk memiliki keterampilan teknik dasar penanganan cedera karena aktivitas olahraga akan berdampak pada cedera.

\section{SIMPULAN}

Hasil penelitian dapat disimpulkan masih rendahnya pemahaman pelatih terhadap penanganan cedera engkel yang bedampak pada keterampilan pelatih dalam melakukan penanganan cedera olahraga khususnya cedera engkel. Teknik penanganan cedera olahraga pada dasarnya sangat mudah dipahami jika dengan dipahami teknik dan prinsip-prinsip dasar. Keterlibatan pemerintah, asosiasi, organisasi dan lembaga pendidikan tinggi hendaknya turut aktif berpartisipasi dalam meningkatkan pemahaman pelatih dalam penanganan cedera olahraga dengan meyelenggarakan workshop atau pelatihan-pelatihan yang bertujuan meningkatkan keterampilan pelatih atau pelaku olahraga lainnya dalam penanganan cedera olahraga. Keterampilan ini akan menunjang profesionalisme karir dan menjadi peluang ekonomi dalam dunia olahraga.

\section{DAFTAR PUSTAKA}

Calatayud, J., Borreani, S., Colado, J. C., Flandez, J., Page, P., \& Andersen, L. L. (2014). Exercise and ankle sprain injuries: A comprehensive review. Physician and Sportsmedicine, 42(1), 88-93. 
Childs, S. G. (2012). Syndesmotic ankle sprain. Orthopaedic Nursing, 31(3), 177184.

Czajka, C. M., Tran, E., Cai, A. N., \& DiPreta, J. A. (2014). Ankle sprains and instability. Medical Clinics of North America, 98(2), 313-329.

Fong, D. T., Chan, Y.-Y., Mok, K.-M., Yung, P. S., \& Chan, K.-M. (2009). Understanding acute ankle ligamentous sprain injury in sports. $B M C$ Sports Science, Medicine and Rehabilitation, 1(1), 1-14.

Fousekis, K., Tsepis, E., \& Vagenas, G. (2012). Intrinsic risk factors of noncontact ankle sprains in soccer: A prospective study on 100 professional players. American Journal of Sports Medicine, 40(8), 18421850.

Glloway, J., \& Hannaford, D. (2010). Running injuries treatment and prevention. Indianapolis: Meyer \& Meyer Sport.

Hubbard, T. J., \& Hicks-Little, C. A. (2011). Guideline for diagnosis and treatment of acute inversion trauma of the ankle in athletes. Nederlands Tijdschrift Voor Geneeskunde, 155(33).

Kadel, N. (2018). Foot and Ankle Injuries in Dancers. Performing Arts Medicine, $19(2), 63-76$.

Menetrey, J. (2014). Foreword. European Instructional Lectures, 13(612-625).

Minigh, J. L. (2007). Sports medicine.

Mulligan, E. P. (2011). Evaluation and management of ankle syndesmosis injuries. Physical Therapy in Sport, 12(2), 57-69.

Pasanen, K., Ekola, T., Vasankari, T., Kannus, P., Heinonen, A., Kujala, U. M., \& Parkkari, J. (2017). High ankle injury rate in adolescent basketball: A 3year prospective follow-up study. Scandinavian Journal of Medicine and Science in Sports, 27(6), 643-649.

Pryor, J. L., Root, H. J., Vandermark, L. W., Pryor, R. R., Martinez, J. C., Trojian, T. H., DiStefano, L. J. (2017). Coach-led preventive training program in youth soccer players improves movement technique. Journal of Science and Medicine in Sport, 20(9), 861-866.

Renstrom, P., Wertz, M., Incavo, S., Pope, M., Ostgaard, H. C., Arms, S., \& Haugh, L. (2014). Strain in the lateral ligaments of the ankle.

Rolf, C. (2007). Sports injuries the handbook (1st ed.). London: A \& C Black.

Sculco, P. K., Lazaro, L. E., Little, M. M., Berkes, M. B., Warner, S. J., Helfet, D. L., \& Lorich, D. G. (2016). Dislocation is a risk factor for poor outcome after supination external rotation type ankle fractures. Archives of Orthopaedic and Trauma Surgery, 136(1), 9-15.

Van den Bekerom, M. P. J., Kerkhoffs, G. M. M. J., McCollum, G. A., Calder, J. D. F., \& van Dijk, C. N. (2013). Management of acute lateral ankle ligament injury in the athlete. Knee Surgery, Sports Traumatology, Arthroscopy, 21(6), 1390-1395.

Walker, B. (2013). The anatomy of sports injuries: your illustrated guide to prevention, diagnosis and treatment.

Whatman, C., Walters, S., \& Schluter, P. (2018). Coach and player attitudes to injury in youth sport. Physical Therapy in Sport, 32, 1-6. 